IZA DP No. 6153

Revealing Taste-Based Discrimination in Hiring:

A Correspondence Testing Experiment with Geographic Variation

Magnus Carlsson

Dan-Olof Rooth

November 2011 


\title{
Revealing Taste-Based Discrimination in Hiring: A Correspondence Testing Experiment with Geographic Variation
}

\author{
Magnus Carlsson \\ Linnaeus University \\ Dan-Olof Rooth \\ Linnaeus University, \\ CReAM and IZA
}

\section{Discussion Paper No. 6153 \\ November 2011}

\author{
IZA \\ P.O. Box 7240 \\ 53072 Bonn \\ Germany \\ Phone: +49-228-3894-0 \\ Fax: +49-228-3894-180 \\ E-mail: iza@iza.org
}

Any opinions expressed here are those of the author(s) and not those of IZA. Research published in this series may include views on policy, but the institute itself takes no institutional policy positions.

The Institute for the Study of Labor (IZA) in Bonn is a local and virtual international research center and a place of communication between science, politics and business. IZA is an independent nonprofit organization supported by Deutsche Post Foundation. The center is associated with the University of Bonn and offers a stimulating research environment through its international network, workshops and conferences, data service, project support, research visits and doctoral program. IZA engages in (i) original and internationally competitive research in all fields of labor economics, (ii) development of policy concepts, and (iii) dissemination of research results and concepts to the interested public.

IZA Discussion Papers often represent preliminary work and are circulated to encourage discussion. Citation of such a paper should account for its provisional character. A revised version may be available directly from the author. 
IZA Discussion Paper No. 6153

November 2011

\begin{abstract}
Revealing Taste-Based Discrimination in Hiring: A Correspondence Testing Experiment with Geographic Variation

The standard correspondence testing experiment does not identify whether employer prejudice drives discriminatory behavior when hiring. This article proposes a new methodology using geographic variation to explore the link between employer attitudes toward ethnic minorities and the ethnic difference in callbacks for a job interview. Using already existing Swedish data we find that a randomly selected employer is more likely to discriminate against a minority job applicant in regions where the average employer has more negative attitudes.
\end{abstract}

JEL Classification: $\quad \mathrm{J} 64, \mathrm{~J} 71$

Keywords: field experiments on hiring, employer discrimination, negative attitudes, regional variation

Corresponding author:

Dan-Olof Rooth

School of Business and Economics

Linnaeus University

39182 Kalmar

Sweden

E-mail: Dan-Olof.Rooth@Inu.se

\footnotetext{
* A research grant from the Faculty of Business, Economics and Design at Linnaeus University and another from the Swedish Council for Working Life and Social Research are gratefully acknowledged.
} 


\section{Introduction}

Ethnic wage differentials, self-reports of perceived discrimination, and population attitude surveys indicate a large role of ethnic discrimination in shaping labor market outcomes for minority workers in Europe. However, the inherent difficulties in identifying the impact of employer prejudice on, e.g., standard wage regressions have inspired researchers to conduct so called correspondence testing experiments (henceforth CTE) in the real labor market. ${ }^{1}$ In CTEs, fictitious job applications which only differ with respect to the applicant's group membership (e.g., ethnic majority vs. minority sounding names) are sent to real job openings. The degree of discrimination is then quantified by calculating the difference in the probability of being invited to a job interview for the two groups of applicants. The main advantage of this method is that, by construction, it guarantees that the researcher and the employer will observe the same characteristics of the applicant, and any difference in the probability of being invited to a job interview must be due to the employers' reaction to the name of the applicant.

Although this experimental design truly wipes out the role of supply side factors and pinpoints that discriminatory acts exist, it is still ignorant about its cause. ${ }^{2}$ Knowing whether any discriminatory treatment in a market, at least partly, is due to employer preferences against employing minority workers is crucial for what policy recommendation to make. Hence, it is not surprising that the economic literature has tried to provide evidence, and ultimately disentangle, the causes of discriminatory treatment,

\footnotetext{
${ }^{1}$ See Riach and Rich (2002) for a summary of European and US situation experiments.

${ }^{2}$ See Heckman (1998) for details.
} 
especially in relation to labor market outcomes. ${ }^{3}$ Due to space limitations and our focus on detecting prejudice using CTEs we only discuss the design and results of one closely related study.

The obvious way to proceed in order to reveal whether employer prejudice affects ethnic discrimination in the hiring process would be to investigate employer attitudes directly, i.e., by interviewing them. In a recent attempt to identify the existence of prejudice in hiring, Rooth (2010), measured explicit as well as implicit attitudes of the recruiters participating in his experiment. He found that recruiters with more negative implicit attitudes, but not with more negative explicit attitudes, are less likely to invite applicants with a typical Middle Eastern name to a job interview compared to applicants with a typical Swedish name.

While certainly being a step forward in identifying the role of prejudice in hiring there are also shortcomings with such a strategy. If only a limited number of employers decide to participate, selection issues might affect the result. Also, an important question is whether employers actually reveal their true explicit attitudes towards the minority in such a setting. If not, measurement error might hide any existing link between employer explicit attitudes and their hiring behavior.

In this paper we propose a new methodology to reveal whether attitudes are important or not for employers hiring decisions. In doing so we suggest conducting a CTE with geographic variation and to combine it with (already existing) population attitudes against the minority. Hence, instead of exploring variation in employer attitudes across firms, it utilizes variation in population attitudes across geographic areas, and, then

\footnotetext{
${ }^{3}$ See for example List (2004).
} 
relates it to the ethnic difference in callback rates. To our knowledge this is the first time such a strategy has been implemented in the CTE setting and compared to asking employers directly about their attitudes, it has several advantages. ${ }^{4}$ First, if data on population attitudes exist and are freely available, the marginal cost to implementing the design is small. Second, using population attitudes that are collected in an anonymous setting probably lessens the critique of employers not revealing their true attitudes. Third, the participation rate on attitude surveys is usually quite high and hence, there is less room for selective participation effects to distort the interpretations.

\section{Methods}

\subsection{The correspondence testing experiment}

The data were obtained from a field experiment measuring the extent of ethnic discrimination in the whole of Sweden. The data was collected between March and November 2007, see Rooth (2011) for details of the design. Real-life (written) applications from the webpage of the Swedish employment agency, adjusted and calibrated for our purposes, were used as templates. The application consisted of a general biography on the first page and a detailed CV, including education and work experience, on the second page. Jobs in selected occupations (see below) and found on the Swedish Employment Agency's webpage were applied for. The applications were randomly assigned a Swedish or Middle Eastern sounding name.

\footnotetext{
${ }^{4}$ However, using geographical variation in attitudes is not new and has been used in other research settings, see for instance Charles and Guryan (2008).
} 
The descriptive results of the field experiment are summarized in Table 1. 2,837 applications with a typical Swedish name were sent, which in 762 cases resulted in an invitation to an interview. This corresponds to a callback rate of 26.9 percent. The corresponding figures for applicants with a typical Middle Eastern name are 2,820, 491, and 17.4 , respectively. Hence, on average, there is a statistically significant difference of 9.5 percentage points in the callback rate, favoring applicants with a typical Swedish name.

\subsection{Majority attitudes toward the ethnic minority}

Our measure of employer attitudes is obtained from FSI, a Swedish research institute that measures attitudes of the Swedish population on various dimensions. Since we use survey data on the attitudes of the general public and not the employers, we make the assumption that the attitude of the general public is an approximation of employers' attitudes in a region. The FSI survey is conducted each year on a random sample of individuals in the population, and by merging the years 2000 to 2008, a sample consisting of 19,555 respondents was obtained. The attitude measure that we use is constructed from the following question (own translation from Swedish): "What do you think of the immigrants that we have received as a contribution to the Swedish population?". The possible answers are: 1) “Very valuable”, 2) “Quite valuable” 3) “Not very valuable”, and 
4) "Not valuable at all". 5 Based on information about in which municipality the respondent lived at the time of the survey, we construct two different average attitude measures at the municipality level. The first measure is defined as the share in a municipality that responded either "Not very valuable” or "Not valuable at all”. Figure 1 shows the distribution of this measure for the 290 municipalities in Sweden.

*** Figure 1 about here ***

However, since there are few respondents in some municipalities we suspect measurement error in the attitude measure to be an issue, biasing our results towards zero. Therefore we construct an alternative attitude measure by simply dividing the municipalities into two groups - whether the share of respondents with negative attitudes in the municipality is below or above the Swedish average. Although being a more rough measure the problem with measurement error should be reduced since most municipalities are expected to be correctly classified as being above or below the average.

\section{Results}

In order to reveal whether negative attitudes toward immigrants are important in the hiring process we relate regional variation in average attitudes to regional variation in the ethnic difference in the probability of being invited to a job interview. Using all 5,637

\footnotetext{
${ }^{5}$ A future study could improve upon our study by using differently phrased questions allowing for more detailed answers.
} 
applications, we estimated the following equation using a Probit model (reporting marginal effects from the dprobit command in Stata and clustering standard errors on job advertisement level). ${ }^{6}$

Callback $_{i}=\alpha+\beta_{1}$ Minority $_{i}+\beta_{2}\left[\begin{array}{l}\text { Attitudes in } \\ \text { municipality }\end{array}\right]_{i}+\beta_{3}\left[\begin{array}{l}\text { Attitudes in } \\ \text { municipality }\end{array}\right]_{i}$ Minority $_{i}+\varepsilon_{i}$

Callback $_{i}$ is an indicator that equals one if sending application $i$ resulted in a job interview offer, $\alpha$ is the intercept for applicants with a typical Swedish name, while $\beta_{1}$ is the difference in the intercept for applicants with a typical Middle Eastern name, $\beta_{2}$ is the slope coefficient of the attitude variable for applicants with a typical Swedish name, and, finally, the parameter of interest is $\beta_{3}$, which measures the difference in the slope coefficient of the attitude variable for applicants with a typical Middle Eastern name. In other words, $\beta_{3}$ reflects if the attitude toward ethnic minorities in the municipality correlates with the probability of being invited to an interview for applicants with a typical Middle Eastern name, compared to applicants with a typical Swedish name.

The results when using the continuous measure of the share of employers with negative attitudes in the municipality are presented in the first two columns of Table 2 . The parameter estimate is negative in the first column including all occupations, but only

\footnotetext{
${ }^{6}$ Estimating a linear probability model resulted in almost identical results.
} 
statistically significant in the second column when only low-skilled occupations are included. $^{7}$

\footnotetext{
*** Table 2 about here $* * *$
}

Next we re-estimated the models in column 1 and 2 instead defining municipalities according to having above average negative attitudes. The main finding is that in municipalities with more negative attitudes, especially for low skilled occupations, applicants with a typical Middle Eastern name are discriminated to a larger extent. Also, this measure of attitudes renders estimates that are more statistically significant. Hence, our results indicate a link between public prejudice, employer prejudice and discrimination in the hiring process.

\section{Conclusion}

We propose a new methodology to reveal if employer prejudice plays a role in the hiring process by taking advantage of already existing data from a large attitude survey and to combine it with a correspondence testing experiment with geographic variation. We test this method using Swedish data and find clear indications of prejudice operating in the hiring process of minority workers.

\footnotetext{
${ }^{7}$ The reason for focusing on low skilled occupations is because there is very little ethnic discrimination in high skilled occupations, see Rooth (2010), potentially making it difficult to empirically identify a link between prejudice and behavior when merging all occupations.
} 


\section{References}

Charles, K. \& Guryan, J. (2008) "Prejudice and Wages: An Empirical Assessment of Becker's The Economics of Discrimination”, Journal of Political Economy, 116(5): 773809.

Heckman, J. (1998) “Detecting discrimination”, Journal of Economic Perspectives, 12: 101-16

List, J. (2004) “The Nature and Extent of Discrimination in the Marketplace: Evidence from the Field”, Quarterly Journal of Economics, 119(1): 49-89.

Riach, P. \& Rich J. (2002) "Field Experiments of Discrimination in the Market Place", The Economic Journal, 112: 480-518.

Rooth, D-O (2010) “Automatic associations and discrimination in hiring: Real world evidence," Labour Economics, 17(3): 523-534.

Rooth, D-O (2011) "Work Out or Out of Work: The Labor Market Return to Physical Fitness and Leisure Sport Activities”, Labour Economics, 18(3): 399-409. 


\section{Figures:}

Figure 1 . The share of respondents in a municipality with negative attitudes.

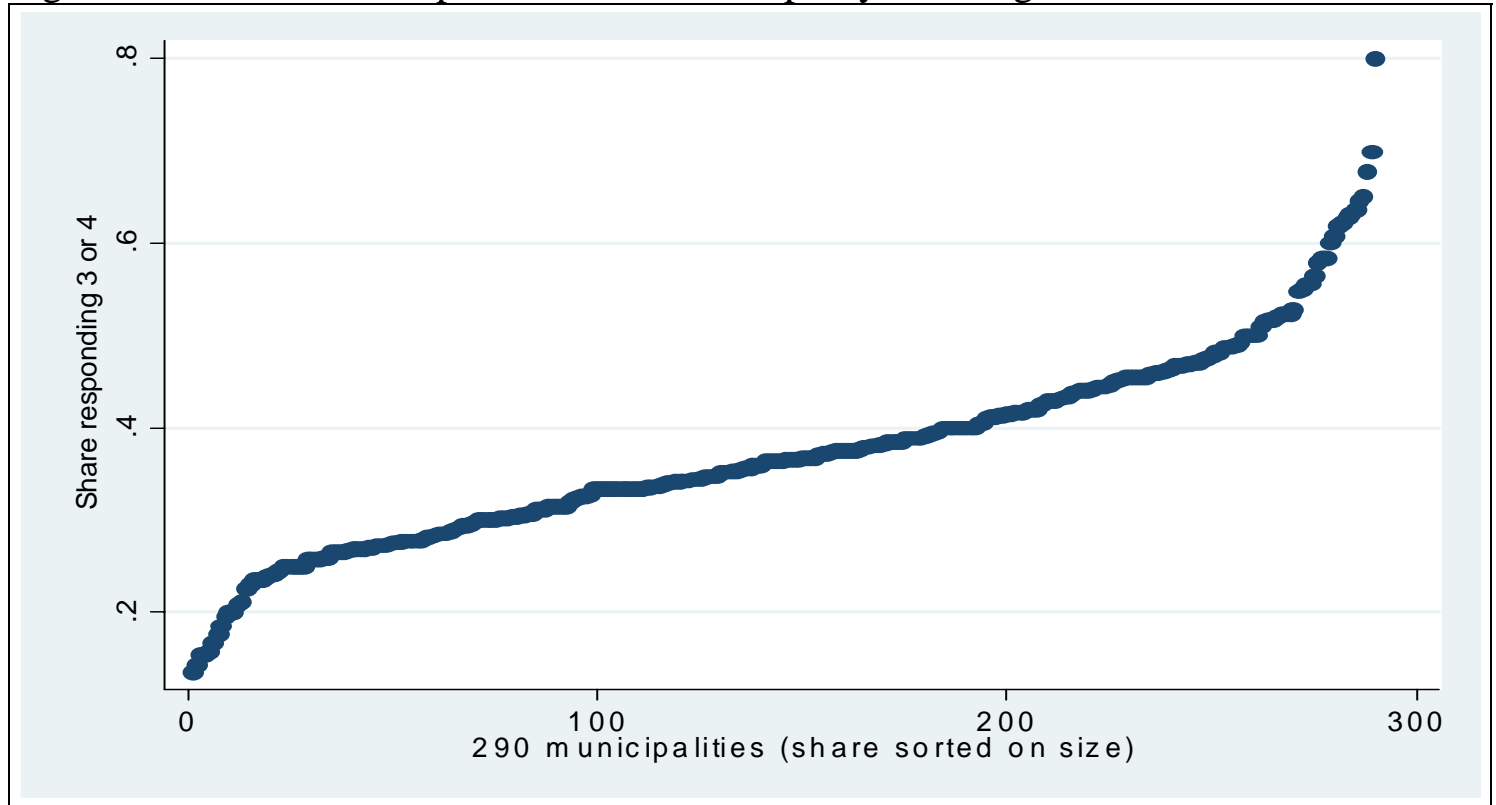

Source: FSI-data 2000-2008. 


\section{Tables:}

Table 1. Result for the correspondence testing experiment.

\begin{tabular}{lccc}
\hline \hline & $\begin{array}{c}\text { Typical } \\
\text { Swedish name } \\
\text { No. jobs }=2,837\end{array}$ & $\begin{array}{c}\text { Typical } \\
\text { Middle Eastern name } \\
\text { No. jobs }=2,820\end{array}$ & Difference \\
\hline No. invitations to interview & 762 & 491 & \\
Callback rate & 26.9 & 17.4 & $9.5^{* * *}$ \\
\hline \hline
\end{tabular}

Note: This table reports the total result of the experiment. The critical $\chi^{2}$-value at the one percent level of significance is $6.63\left({ }^{* * *}\right)$. The McNemar statistic for paired proportions is applied.

Table 2 . The probability of being invited to a job interview.

\begin{tabular}{|c|c|c|c|c|}
\hline & $\begin{array}{l}\text { All } \\
\text { occupations }\end{array}$ & $\begin{array}{l}\text { Low skilled } \\
\text { occupations }\end{array}$ & $\begin{array}{l}\text { All } \\
\text { occupations }\end{array}$ & $\begin{array}{l}\text { Low skilled } \\
\text { occupations }\end{array}$ \\
\hline Middle Eastern name & $\begin{array}{l}-0.03 \\
{[0.05]}\end{array}$ & $\begin{array}{c}0.00 \\
{[0.05]}\end{array}$ & $\begin{array}{l}-0.09^{\star \star \star} \\
{[0.01]}\end{array}$ & $\begin{array}{l}-0.08^{\star \star \star} \\
{[0.01]}\end{array}$ \\
\hline Share negative attitudes & $\begin{array}{l}-0.11 \\
{[0.12]}\end{array}$ & $\begin{array}{l}-0.10 \\
{[0.13]}\end{array}$ & $\begin{array}{c}0.00 \\
{[0.02]}\end{array}$ & $\begin{array}{c}0.00 \\
{[0.02]}\end{array}$ \\
\hline $\begin{array}{l}\text { Middle Eastern name * } \\
\text { Share with neqative attitudes }\end{array}$ & $\begin{array}{c}-0.19 \\
{[0.15]}\end{array}$ & $\begin{array}{l}-0.29^{*} \\
{[0.17]}\end{array}$ & - & - \\
\hline $\begin{array}{l}\text { Middle Eastern name * } \\
\text { Share with negative attitudes above average }\end{array}$ & - & - & $\begin{array}{l}-0.05^{*} \\
{[0.03]}\end{array}$ & $\begin{array}{l}-0.07^{* *} \\
{[0.03]}\end{array}$ \\
\hline 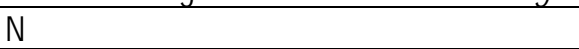 & 5,635 & 3,532 & 5,635 & 3,532 \\
\hline
\end{tabular}

